\title{
Analyzing Gender Role Representations of Serial Killers in "Dexter"
}

\author{
Ceyda Kuloğlu ${ }^{1}$ and Oğuzcan Karakaya ${ }^{2}$ \\ ${ }^{1}$ Assistant Professor, Department of Sociology, Başkent University, Turkey \\ ${ }^{2}$ Research Assistant, Department of Sociology, Başkent University, Turkey
}

\begin{abstract}
TV series are used as mediums to reflect personal troubles and public issues, which are connected to each other with the concept of "sociological imagination". In other words, it is the awareness of personal experience and wider society relationship and is used in the TV series to reflect the social reality. Without gender role representation, analyzing the reflection of reality in the TV shows would be inadequate. In order to analyze the gender role representations, one of the Showtime TV series, "Dexter" will be used as a case study. Besides gender role representation in "Dexter", because the show is based on a serial killer character, Dexter Morgan, serial killer typologies and their effective usage in the episodes will be discussed.

The aim of this study is to sociologically analyze the gender role representations with the serial killer typologies of the characters in Dexter. There are basically four serial killer typologies for men and seven for women. These are visionary, mission-oriented, hedonistic, power/control oriented for men and black widow, angel of death, sexual predator, revenge, profit or crime, team killer, question of sanity for women.
\end{abstract}

Keywords: Gender, Serial Killers, Visual Sociology

\section{Introduction}

Serial killers have a long history since 331 B.C. in the world [1]. It is considered that they have two or more victims at least in two separate events and after a cooling-period. Motive and aim of the serial killers are various. Most of the $20^{\text {th }}$ century serial killers are from North America [2]. Whereas there are few serial killers in Turkey, the reason of this difference can be from lack of success in the investigation process in Turkey, which in other words, there may be more serial killers in Turkey that has not been come to light. There are some serial killers in Turkey but the number of them is contradictory subject as well as the dispute if some of them actually serial killers or spree killers, but none of them are female. Serial killing and the murderers are important issues in order to evaluate gender stereotypes in the traditional patriarchal society. Because serial killer investigation and observance situations are inadequate in Turkey, a popular TV show, Dexter, was chosen as the case in this study. Female and male serial killer stereotypes are very well represented in Dexter. In this regard, the aim of this study is to examine the similarities and differences of serial killers between sexes and to determine how these stereotypes reflect the gender roles in the society. Whether Dexter challenge or reproduce the traditional gender roles in patriarchal society by using serial killers typology is the main research question of the paper.

\section{Defining the "Serial Murder"}

Serial murders are an intriguing subject among both public and media. Apart from homicide where the murderer mostly gets caught rapidly or at least there is a perception solution of, serial murders has a mystery of their own. They are rarely seen when compared to total amount of homicide, but always get public attention.

Although the serial killings have always been around, the term "serial murderer" never been used before late 1950s [3][4]. By the mid-1960s the term became more common and used describing the particular type of a multiple killing [4]. Even though the term is being used frequently there are still some disputes over what kind of multiple killings count as serial murders. The main dispute is on the count of victims. Considering the 
definitions, the count of victims varied from two to ten and incidents varied from two to six [3][5]. Commonly used definitions of serial murders are:

- "...three or more separate events in three or more separate locations with an emotional cooling off period in between homicides. "(p.96) [6]

- "The unlawful killing of two or more victims by the same offender(s), in separate events. ”(p.9)[5]

- $\quad$ Three or more killed people in more than 30 days with a notable period between the murders [7].

Despite the differences there are many similar points in all of the definitions which are;

- Same offender(s),

- At least two or more victims,

- Separate events,

- A period of time.

Even with all these similarities, still there is not a single standard definition of serial murder in media or scientific research. Thus the terms "serial murder", "spree murder" and "mass murder" can be used for each other especially in media sources. The media's effect on definition can also vary according to reporters own view [8]. In a recent incident in Turkey, a group of two went on a killing spree for 3 days before getting caught. The media described them as serial killers instead of spree murderers and still doing so despite the basis of serial murder term. Like in this situation the separate events and time period also added to the definitions to differentiate serial murders from mass killings. Mass killing includes four or more victims at one time in the same incident and event; though it can be combined with spree murder when the killer goes to more than one place [6].

Holmes and Holmes [7] defined different phases in serial murder relating to this: fantasy, stalk, abduction, kill and disposal also noting that not all of them have to be present in each case. The serial killer doesn't kill with frequency like in spree murders to avoid detection. Also he may take mementos from victims and in that way he can relive the crime and extend the fantasy [6]. Extension of fantasy is actually the cooling-off period of serial murder which is also the start point of the crime.

After explaining serial murder there is one more question: Who are serial killers?

Different continents, different countries produced many serial killers in the line of history. And it is safe to say there is no typical stereotype. But there are some common concepts among researchers. Many of the researches agree on that almost all of the serial murder cases (mostly male offenders) include a sexual element in themselves [3][5][8][9]. According to Douglas et. al.[6] a serial murderer's targets are usually strangers sharing similarities in each other. The motives and reasons mostly remain unknown and they are unique to each offender [5]. Even though their motives are unique, those motives have been categorized as "sex", "greed", "religious", "mercy", "insanity", "racism" and "revenge"[3]. Still there were attempts to form a typology of serial killers. Today the most commonly used typology is formed by Holmes and DeBurger [10]. They formed their typology by major serial killing cases considering the motives behind them. According to Holmes and DeBurger [10] there are four types of serial killers: Visionary, Mission-Oriented, Hedonistic, Power/Control Oriented.

Visionary type: They are killing based on visions they see or sounds they hear. The voices or visions can be seen or heard in a good or evil form, usually commanding. They are usually described as psychotic.

Mission-Oriented: They are not psychotic killers. They have a sense of mission to remove certain types of unwanted people or groups. This mission is self-imposed.

Hedonistic Type: They seek thrill and take joy of the murder. There is no goal or outside voices/visions in this group. They kill for their own enjoyment. Also the "lust" has been described as a sub-category which comes from sexual excitement during the homicide.

Power/Control Type: The idea is holding power over someone else for this type of serial killer. To directly quote Holmes and DeBurger [10] "Holding the power of life or death over a victim is symbolically the ultimate control that one person can exert over another." $(p .33)$ and by doing this the killer gets excitement and pleasure simply by having the total control of the situation and knowing he can do whatever he wishes to do and it is in his power.

As it is apparent those types are formed for mainly male serial killers. Holmes and Holmes [7] tried to formulate a typology for female serial killers in their original work based on the male typology but the most 
commonly used typology is Kelleher and Kelleher's [11] work on female serial killers which will be discussed in the next section.

\subsection{Female Serial Killers}

Violence by women had very little consideration by the theorists. It is when violence rates are compared it has seen that women commit violence less than men. "Sex differences in rates of violence by men and women are consistent, with men outnumbering women by a very large margin. This is so across countries, over time, at all ages and in relation to different types of violence"(p. 7) [12].

Although women's violence is described as a "response to an abusive situation or past abusive experiences" (p. 5) by feminists [12], violence by women is still seen as "unnatural" and "unfeminine" and as an mental instability. "Traditional stereotypes of women as nurturing, gentle, passive and submissive, deny any possibility of aggression or violent behavior as natural female response"(p. 13) [12]. It is argued that, female killers are the murderers that use violence in response to patriarchy [13] and if women commit murder, it is usually a close partner or relative [12].

In order to follow the traditional gender roles, women should act as feminine, which means act, dress and present themselves as a lady and society has no room for an opposite female stereotype. This is why when female serial killers is the case, media and public approach to women murderers differently than male serial killers. The female murderer is usually classified as "mad" or "bad" by media. When the female murderer is defined as mad, there is a public view of sadness towards the criminal as she is insane or helpless and this in turn underestimates her actions. On the other hand, when she is defined as bad, she becomes the person that acts opposite to the expectations from her sex, which in turn labels the woman as evil [14].

The first female serial killer in the history, Aileen Wuornos, is the best example for the representation of "bad" murderer. The trial of Wuornos gained a very much public attention and even the movie "monster" was based on this true story of first female serial killer. She killed seven men in one year during her prostitution work on Florida highways. First she claimed that these murders were self-defense, but then she confessed that she committed these crimes in order to rob men's money, which made her "bad" instead of "mad" female murderer. She were executed by lethal injection on October $9^{\text {th }}, 2002$ [14].

There are basically three sociological theories that deal with female serial killers: Labeling, Anomie and Chivalry Theory. According to labeling theory, "if the original self-image of the criminal is weak and unstable, then this labeled person may come to accept the image that is offered by others and change their self-image as they see fit" [14]. In the case of the Aileen Wournos, she was defined as "social outcast, filthy prostitute and violent bisexual". Because she did not fit in the social categories of femininity, the case focused her character and a strong stigma was attached to her. She was labeled as violent and possessed woman and also viewed as an "evil monster", who must be killed so that she could not kill again [14].

The second theory, anomie, deals with the media and public views and describes the position of public and media, when they come across a female murderer, as if they "enter a frenzied state". In these cases, empathy and other notions of society just finish and the stereotypical gender roles come into focus. In Aileen Wournos case, because the public could not describe this criminal in stereotypical notions and became normless and stuck in confusion, media and public described Wournos as inhuman, unfeminine and monster [14]. According to Berrington and Honkatukia [15], "women's violent behavior, particularly if they kill, is depicted as a threat to the stability of patriarchal and familial relations and expectations".

The final theory, chivalry, argues that because of the patriarchal system of criminal justice, female offenders are treated in a more gentle way just because of their sex. For example, in the Aileen Wournos case, because the killings were more masculine and violent, and because masculine crimes of females are evaluated as more serious than male murderers, she was criminalized by death sentence. In some other cases, this was not the result just because they did not cross the society's gender role borders [14].

According to Keeney and Heide [16], the differences between male and female serial killers are more than the similarities. The similarities between two sexes can be summarized as both of their past broken family lives, childhood abuse, race, low educational level and occupation. On the other hand, the differences of serial killers according to sex are, victim damage, victim torture, weapon and method, stalking versus luring behaviours, crime scene organization, reason for murders, substance abuse history, psychiatric diagnosis and household 
composition. Unlike male serial killers, female serial killers mostly use poison to murder their victims. Besides poisoning, they also use shooting, bludgeoning, suffocation, stabbing and drowning [9]. As Kelleher and Kelleher [11] mention, unlike men, female serial killers are more successful, careful, precise, methodical and quite when they are committing murder. Although there are differences between male and female serial killers the main common point is to destroy human beings [16].

In criminology literature there are different types of female serial killers. First type is the "black widow", who seduces men, makes love, marries and then kills men in order to benefit from their money. Killing motivation of the black widows can be revenge, to control and/or to direct men. Black widows' victims are usually from their own family, especially her husbands. Second type of female serial killers is "angel of death", who are usually nurses and kills their patients to obtain their goods [17]. The victims of angel of death are vulnerable beings usually in institutions, like hospitals or nursing homes. If the mobility of the female serial killer increases, the period of killing also increases. Third type is "sexual predators", who are usually in their 30s and suffer from fantasy-driven killing motive. Fourth type is the "revenge", who kills with a revenge impulse. Victims are symbolic to fulfill the revenge motivation of the female serial killers. "Profit and crime" female serial killers are the fifth category and they kill for economic gains. Victims are generally are not family members in this type of female serial killers. "Team killer" is the sixth type of female serial killers, who kill in cooperation with other person or people, either women or men. The last type of female serial killer is "question of sanity", who is not capable of her acts and the results of her acts. They kill without calculation or planning of killing [11].

\subsection{Serial Killer Characters in Dexter}

If we take the female and male serial killer characters in Dexter, we find out that the differences between male and female serial killers are underlined in this popular TV show. In the show, we may find almost all of the female and male serial killer types. Female serial killers - Mary, Valerie Castillo, Cindy Landon, Hannah Mckay and Lumen Pierce- in Dexter are angel of death, black widow, revenge killer and team killers. Whereas some of the male serial killers -Dexter Morgan, Miguel Prado, Travis Marshall, Jordan Chase- are seen as missionoriented, power/control, visionary and hedonistic killers.

As in told in criminological literature, female and male serial killers in Dexter have different methods of killing. Female serial killers are more cautious than their male counterparts. Although female characters mostly use poisoning in order to avoid getting caught in the show, male serial killers use their physical strength and stab or suffocate their victims. These methods that male characters used are more "personal" and satisfy their power and/or control needs.

The victims of the female characters are more familiar, whereas the male characters choose their victims mostly from strangers to themselves. For example, when we analyze Dexter Morgan, he chooses his victims in a context of his personal mission, which is in order to eliminate people that are "undesirable" and "unworthy" for the society. This in turn, makes him a protagonist, who fulfills his justice need. On the other hand, for example Lumen Pierce killed her victims to satisfy her revenge need after she was gang-raped. In these murders she cooperated with Dexter Morgan, which may be evaluated as to show women's insufficiency.

Although there are various differences between female and male serial killer characters in the TV show, there are also many similarities. These similarities, as discussed in criminological literature, can be summarized as their broken families, damaged childhoods, hurting and destroying human beings. At the end, they all murder their victims in order to satisfy their personal goals. The summary of the characters are shown in Table 1 and Table 2 below. 
TABLE I: Female Serial Killer Characters in Dexter

\begin{tabular}{|c|c|c|c|}
\hline Season/Episode & Character & Type/Method & Properties \\
\hline S01E13 "Popping Cherry" & Mary & Angel of Death/ Poison & $\begin{array}{l}\text { Nurse, kills people to "heal their pains" } \\
\text {-Tries to kill Dexter's stepfather with morphine and } \\
\text { overdose drugs. } \\
\text { - Collecting mementos }\end{array}$ \\
\hline $\begin{array}{l}\text { S01E05 "Love American } \\
\text { Style" }\end{array}$ & $\begin{array}{l}\text { Valerie } \\
\text { Castillo }\end{array}$ & Team Killer/Drowning & $\begin{array}{l}\text { Human trafficker in order to gain economic wealth. } \\
\text { Teamed with her husband. }\end{array}$ \\
\hline S01E06 "Return to Sender" & $\begin{array}{l}\text { Cindy } \\
\text { Landon }\end{array}$ & $\begin{array}{l}\text { Black Widow/ Multiple } \\
\text { Methods }\end{array}$ & $\begin{array}{l}\text { Wife, killed her } 3 \text { husbands in order to gain economic } \\
\text { wealth. }\end{array}$ \\
\hline $\begin{array}{l}\text { S05E03 (first appearance) } \\
\text { and other episodes }\end{array}$ & $\begin{array}{l}\text { Lumen } \\
\text { Pierce }\end{array}$ & $\begin{array}{c}\text { Revenge, Team } \\
\text { Killer/Shooting, Stabbing }\end{array}$ & $\begin{array}{l}\text { Student, gang-raped then killed } 3 \text { members of the gang } \\
\text { with Dexter for revenge. }\end{array}$ \\
\hline $\begin{array}{l}\text { S07E03 (first appearance) } \\
\text { and other episodes }\end{array}$ & $\begin{array}{l}\text { Hannah } \\
\text { McKay }\end{array}$ & $\begin{array}{l}\text { Black Widow, Revenge/ } \\
\text { Poison }\end{array}$ & $\begin{array}{l}\text { Botanist } \\
\text {-Sexually abused by her counselor. } \\
\text {-Poisoned her } 40 \text { years of husband who forced her to have } \\
\text { abortion. Death of the husband attributed to heart attack. } \\
\text {-Poisoned writer to prevent him reveal her murderous past }\end{array}$ \\
\hline
\end{tabular}

TABLE II: Some of the Male Serial Killer Characters in Dexter

\begin{tabular}{|c|c|c|c|}
\hline Season/Episode & Character & Type/Method & Properties \\
\hline $\begin{array}{l}\text { S01-S08 (All } \\
\text { Episodes) }\end{array}$ & $\begin{array}{l}\text { Dexter } \\
\text { Morgan }\end{array}$ & $\begin{array}{l}\text { Power/Control, Hedonistic, Mission- } \\
\text { Oriented/ Stabbing }\end{array}$ & $\begin{array}{l}\text { Blood Analyst, works for Police Department } \\
\text {-Anti-social character(cannot empathize) } \\
\text {-Broken Family, raised by step-family } \\
\text {-Traumatized childhood (witnessed her mother's } \\
\text { murder) } \\
\text {-Tried to control his killing instinct when a child } \\
\text {-Kills people in neat and well-organized crime } \\
\text { scenes } \\
\text {-Planned and well-organized murders and } \\
\text { disposals } \\
\text {-Collecting mementos }\end{array}$ \\
\hline S03E01 to S03E12 & $\begin{array}{l}\text { Miguel } \\
\text { Prado }\end{array}$ & $\begin{array}{c}\text { Hedonistic, Power/Control/ Stabbing, } \\
\text { Suffocating }\end{array}$ & $\begin{array}{l}\text { Assistant District Attorney, } \\
\text {-Damaged childhood (abusive father) } \\
\text {-Killed his colleague because of competition }\end{array}$ \\
\hline S05E07 to S05E12 & $\begin{array}{l}\text { Jordan } \\
\text { Chase }\end{array}$ & $\begin{array}{l}\text { Power/Control, Hedonistic/Convince others } \\
\text { to kill by electrocution }\end{array}$ & $\begin{array}{l}\text { Motivational Speaker, } \\
\text {-Leader of the gang who controls how and whom } \\
\text { to kill to satisfy his sexual desire } \\
\text {-Origin of his murders descends from his teenager } \\
\text { days }\end{array}$ \\
\hline S06E01 to S06E12 & $\begin{array}{c}\text { Travis } \\
\text { Marshall }\end{array}$ & Visionary/ Mostly stabbing & $\begin{array}{l}\text { Conservator in a museum, } \\
\text {-Kills in order to reproduce some paintings and his } \\
\text { religious visions } \\
\text {-Insane } \\
\text {-Killed his parents when he was a child }\end{array}$ \\
\hline
\end{tabular}

\section{Conclusion}

The difference between female and male serial killers clearly mirrors the patriarchal society and the gender roles. In this respect it is not only the traditional gender roles in reflecting the society but it is also reproducing these gender roles in the TV show. We see that while male serial killers have a lofty mission in their murders, female serial killers kill their victims mostly in order to obtain economic gains and revenge. This situation underlines the men's superior position in the society by using serial killers' gender representation in Dexter. On the other hand, we also see how male serial killers mostly have power and control over their victims, unlike female serial killers. This situation represents the women's submissive position in the traditional gender roles in the society. Lastly, although the male serial killers are mostly the main antagonists in the TV show, female serial killers have backup roles in Dexter, who generally are also victims in their previous lives.

In this respect, we may argue from a feminist perspective that as a popular TV show, Dexter reproduces the traditional gender roles in the patriarchal society and do not challenge patriarchal norms of the society by using 
female and male serial killers typologies. In the end, we may argue that Dexter's popularity comes from "justice" need of people living in an unjust society. Dexter Morgan, the main protagonist of the TV show who kills only the "bad" people in the city. This situation may effect on fulfillment of the viewers' justice need, which they may not live in their real lives.

\section{References}

[1] Newton, M. (2010). Criminal Justice: Crime and Criminals. New York: Infobase Publishing.

[2] Newton, M. (2000). Encylopedia of Serial Killers(2nd ed.). New York: Infobase Publishing.

[3] Newton, M. (2008). Criminal Investigations: Serial Killers. New York: Infobase Publishing.

[4] Schechter, H. (2003). The Serial Killer Files. New York: Ballantine Books.

[5] Morton(ed), R. J. (2005). Serial Murder: Multi-Disciplinary Perspectives for Investigators.

[6] Douglas, J. E., Burgess, A. W., Burgess, A. G., \& Ressler, R. K. (2006). Crime Classification Manual: A Standard System For Investigating and Classifying Violent Crimes. San Fransisco: Jossey-Bass.

[7] Holmes, R. M., \& Holmes, S. T. (2001). Murder in America (2nd ed.). California: Sage Publications.

[8] Ferguson, C. J., White, D. E., Cherry, S., Lorenz, M., \& Bhimani, Z. (2003). Defining and Classifying Serial Murder in the Context of Perpetrator Motivation. Journal of Criminal Justice (31), 287-292.

http://dx.doi.org/10.1016/S0047-2352(03)00009-6

[9] Hickey, E. W. (2013). Serial Murderers and Their Victims(6th ed.). Belmont: Wadsworth.

[10] Holmes, R. M., \& DeBurger, J. E. (1985). Profiles in Terror: The Serial Murderer. Federal Probation, 29-34.

[11] Kelleher, M. D., \& Kelleher, C. L. (1998). Murder Most Rare: The Female Serial Killer. New York: Dell Publishing.

[12] Shaw, M., \& Dubois, S. (1995). Understanding Violence by Women: A Review of the Literature. Correctional Series of Canada.

[13] Pearson, K. (2007). The trouble with Aileen Wuornos, Feminism's 'First Female Killer'. Communication and Critical/Cultural Studies (4) 3, 256-275.

http://dx.doi.org/10.1080/14791420701472791

[14] Weatherby, G. A., Blanche, J., \& Jones, R. (2008). The Vakue of Life: Female Killers and the Feminine Mystique. Journal of Criminology and Criminal Justice Research and Education.

[15] Berrington, E., \& Honkatukia, P. (2002). An Evil Monster and a Poor Thing: Female Violence in the Media. Journal of Scandinavian Studies in Criminology and Crime Prevention (3), 50-72.

http://dx.doi.org/10.1080/140438502762467209

[16] Keeney, B. T., \& M.Heide, K. (1994). Gender Differences in Serial Murderes: A Preliminary Analysis. Journal of Interpersonal Violence (9), 383-398.

http://dx.doi.org/10.1177/088626094009003007

[17] İçli, T. (2013). Kadın Suçluluğu. Ankara: Seçkin Yayıncılık 